\title{
THE ROLE OF INFORMATION TECHNOLOGY SYSTEMS IN KNOWLEDGE MANAGEMENT
}

\author{
Kamil SITARSKI \\ Faculty of Management \\ Warsaw University of Technology, 02-524 Warszawa, Poland \\ email:k.sitarski@wz.pw.edu.pl
}

\begin{abstract}
Presented article describes the research on organizational IT knowledge management system model. Research was started with the analysis of current scientific knowledge status on knowledge management as well as supporting the process with Information Technology. Methods of knowledge management systems were analyzed and a system suitable for a case study was selected. Case study results allowed to build a knowledge management system and the model was verified on the basis of knowledge management system prototype research.
\end{abstract}

Key words: information, IT systems, knowledge management systems, knowledge, knowledge management.

\section{Introduction}

According to the World Bank one of the four tasks accompanying the implementation of a knowledge based economy is the "creation of database system, information infrastructure providing different services in gathering, processing and storing of information and knowledge [6]. Gartner Group [10] estimations reveal that even $75 \%$ of expanses on knowledge management are used to finance computer and telecommunication hardware as well as suitable software. This fact shows the important role of IT technology in knowledge management. At the same time in the research on knowledge management corporate portals, performed by the Polish division of KPMG consulting company, a following statement is present: "using many dispersed applications is difficult, time consuming and costly" [20].

This research justifies the need to implement technical solutions integrating dispersed applications and information and knowledge resources in order to perform more accurate decision making and improve organization's activities and as a result aid knowledge management processes.

The article describes the construction and verification process of a knowledge management system in an organization, which includes the following stages: KMS (Knowledge Management System - this abbreviation will be used in the following part of the article) classification method elaboration, KMS analysis method elaboration (case study on existing solutions)analysis of existing knowledge management systems, construction of a knowledge management system in an organi- zation, knowledge management system prototype construction and research on constructed prototype in order to verify the correctness of assumptions of the model.

Elaborated research results can be used by few recipient groups. KMS designers can construct a system compliant with current knowledge level and best practices in the market. Scientists can use the knowledge management system analysis method in order to perform further research and the management system model can be used to create knowledge management system prototypes. High management and IT department managers can use the knowledge management system in order to verify or confirm the selection of a knowledge management system in their organization.

\section{Knowledge management in relation to IT technologies}

Concepts of knowledge and science were subjects of many analyses, starting from Plato and his student Aristotle who started rationalism and empiricism. In modern ages both these trends have found followers among the greatest thinkers and philosophers and evolved thus creating new trends being their modification or synthesis.

Alfred Marshall, one of the first economists who recognized the value of knowledge, claimed that capital is mostly made of knowledge and organization [12]. F. A. Hayek [7] and J.A. Schumpeter [15] were the next researchers of issues connected with the economic aspect of knowledge. They claimed that organization not only has access to common determined knowledge, 
but also can use its own, subjective knowledge. Hayek divided knowledge into open and tacit - different for different circumstances, which can be specific for given organization as well as he emphasized the importance of tacit knowledge.

Along with the development of IT sciences and organizational theory sciences the nature of the decision making and problem solving process became a subject of the research. H.A. Simon [18] in his research built up a theory describing these processes. He recognized that human beings can create new knowledge and use it in decision making during the information processing process. Therefore the organization should minimize the necessity to distribute knowledge and at the same time decrease the weight of knowledge placed on a single employee. This formalized way of activities should be based on explicit knowledge.

Simon omitted tacit knowledge, treating it as a disturbance, even though Michael Polanyi in his works from that period emphasized its significance and stated that "true invention cannot be based only on a set of rules and algorithms. Knowledge is accessible and for general use but at the same time personal, because it is created by people driven by passion and emotions. Knowledge that lies at the basis of accessible knowledge is of fundamental meaning - the entity of knowledge is either tacit knowledge or a knowledge concluded from it" [14].

\subsection{Knowledge management in organization}

Figure 1 presents a modified knowledge pyramid that includes current proportions between: data, information, knowledge, understanding and wisdom as well as determines the possibility of using modern IT systems and organizational structures in order to process them. Knowledge pyramids proposed by D. Skyrme [19] and R. Ackoff [1] were used in creation of this pyramid.

Knowledge definition, which was used in the elaboration of knowledge management system in the organization, is as follows: "knowledge is a combination of experience, information and expert opinion, which assures basis for development and implementation of new experience and information. It is originated and is used in the minds of people who posses this knowledge. In organizations it usually is stored not only in documents or data banks but also in methods of activity and best practices, processes and norms" [4]. Knowledge management system is also basing in the corporate knowledge creation theory and three knowledge management models, which will be described in the following part of the article.

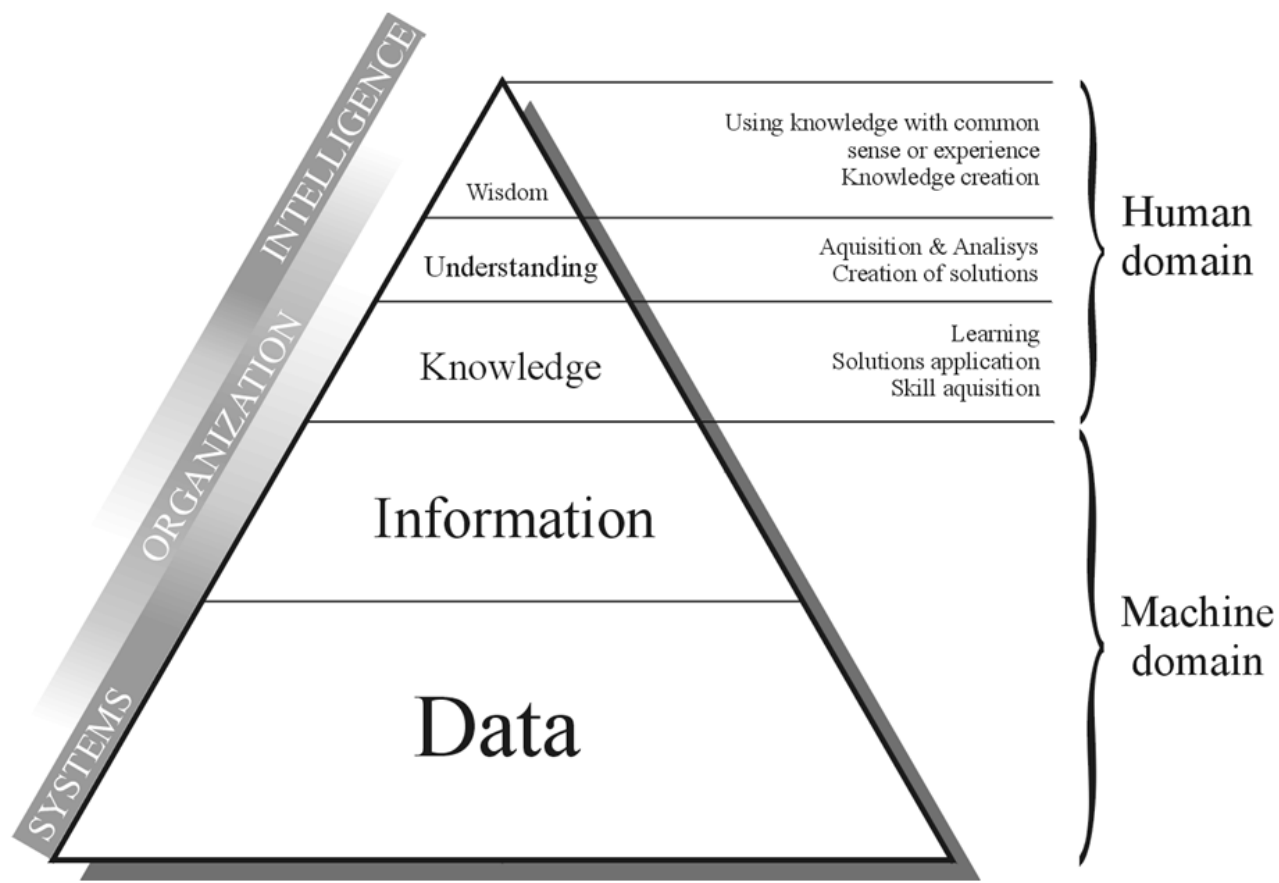

Figure 1. Knowledge pyramid (source: [1] p. 2, [19] p. 2) 


\subsection{Organizational knowledge creation theory}

Theory of organizational knowledge creation of Nonaka and Takeuchi' brings a description of knowledge creation process in an organization. The authors claim that allowing constant changes of one knowledge type into another is a basis for the creation of new knowledge in the organization. This process is defined as knowledge conversion. It distinguishes four modes of knowledge conversion:

- conversion of tacit knowledge into tacit knowledge (socialization),

- conversion of tacit knowledge into explicit knowledge (externalization),

- conversion of explicit knowledge into explicit knowledge (combination),

- conversion of explicit knowledge into tacit knowledge (internalization).

Even though, according to I. Nonaka and H. Takeuchi, organization does not create, it can provide suitable conditions for the creation of it. Authors distinguish five of these organizational conditions:

- organizational intentions - awareness of the strategic value of knowledge,

- empowerment in order to increase motivation level,

- creative chaos, state in which the organization, under the influence of different signals coming from its environment, is able to adjust its knowledge system,

- redundancy - existence of information redundancy for the knowledge creation processes is desirable,

- requisite variety, which allows adjusting the organization to the variety of the environment.

\subsection{Knowledge management models}

The theory of organizational knowledge creation was chosen for the construction of KMS model, due to its holistic description of knowledge creation process. Apart from this theory, three knowledge management models were selected:

- SECI Nonaka model - due to the holistic description of knowledge creation process in the organization as well as distinguishing the " $\mathrm{Ba}$ " cyberspace virtual space in the organization, which on the basis of existing knowledge creates and regularizes new knowledge [13],

- Probst, Raub and Romhardt model - due to its orientation towards practical aspects of knowledge management and a description of particular knowledge management processes [16],

- Carayannis model - due to its possibility so support the knowledge management evaluation process through the determination of knowledge possession in particular areas of the enterprise's activity [2].

These models will be used to build a relation model for the knowledge management system in the organization.

\section{Method for knowledge management systems classification}

One of the basic assumptions in the creation of a KMS model is to use the results of case studies of existing knowledge management systems. Selection of systems suitable for research required the use of a method, which would allow classifying given system as a KMS. The following were used in the elaboration:

- KM Connection company method [21],

- method elaborated by R. Cobos, J.A. Esquivel and X. Alaman [3],

- copyrighted method named Extended Classification Method - ECM.

KM Connection and R. Cobos, J.A. Esquivel and $\mathrm{X}$. Alaman methods were selected on the basis of literature study. ECM method is an expansion and regularization of these two methods. The ECM method has the following criterion, which allows recognizing KMS, determined:

- knowledge management system, similarly to the KM Connection method, must be dedicated to aid knowledge management processes and cannot be a part of systems excluded by KM Connection,

- system stores knowledge in a structured manner, which is not dependent on the knowledge object format (text, graphics, sound, multimedia), as well as is equipped with categorization and relation identification mechanisms (possibly automatic),

- system uses systems that allow automatic gathering of knowledge from external sources (inside and outside of the organization),

- system allows intuitive search of necessary knowledge as well as its browsing in networked and hierarchical manner,

- system supports its users in knowledge base use, simplifying and automating the process, as well as assuring the influence of users on the quality of the information, 
- system aids individual knowledge sharing of particular organization participants as well as provides mechanisms for efficient communication and teamwork.

Apart from fulfilling the listed requirements, KMS should assure a determined level of security for gathered knowledge (key resource of the enterprise) as well as provide mechanisms for reporting and controlling of functioning of the system and its users. Figure 2 presents the relations between particular methods.

\section{$4 \quad$ Case study}

In order to construct a relation model for KMS an analysis of existing KMS was necessary (case study). Case study included the following steps:

- selection of systems to perform research,

- preliminary research,

- detailed research,

- synthetic KMS research results.

Block scheme of the course of the case study is presented in the Figure 3.
Due to considerable amount of solutions, determining systems as KMS, present in the market, selection of the system for research was done in three steps. First step used three groups of systems, used for knowledge management, elaborated by the Business.com, Inc., KM World Magazine and the KM Connection, as well as systems provided by Polish manufacturers (196 systems altogether).

Al systems categorized as knowledge management systems were selected for further study (both Polish and foreign). Next step included verification of 37 (33 foreign and 4 Polish) solutions according to: its functionality (determination whether the system that is claimed to be KMS by its manufacturer truly fulfills all knowledge management system's requirements) and is it up-to-date (whether the system is continuously developed and is the company still present in the market). As a result of this analysis 16 systems were selected, which were analyzed with preliminary questionnaires based on KMS classification method, especially the Extended Classification Method.

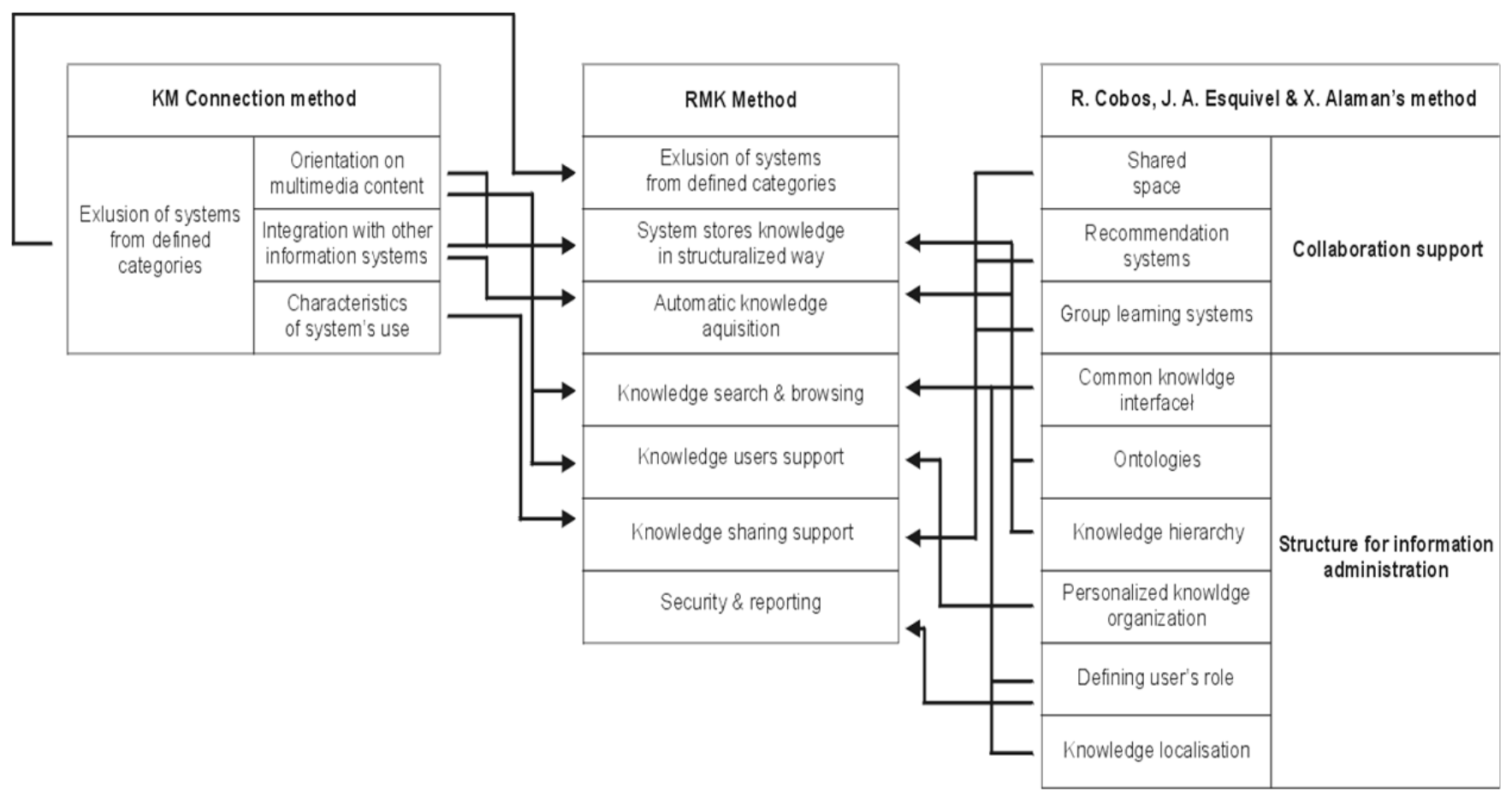

Figure 2. Relations between knowledge management systems classification methods (source: self study) 


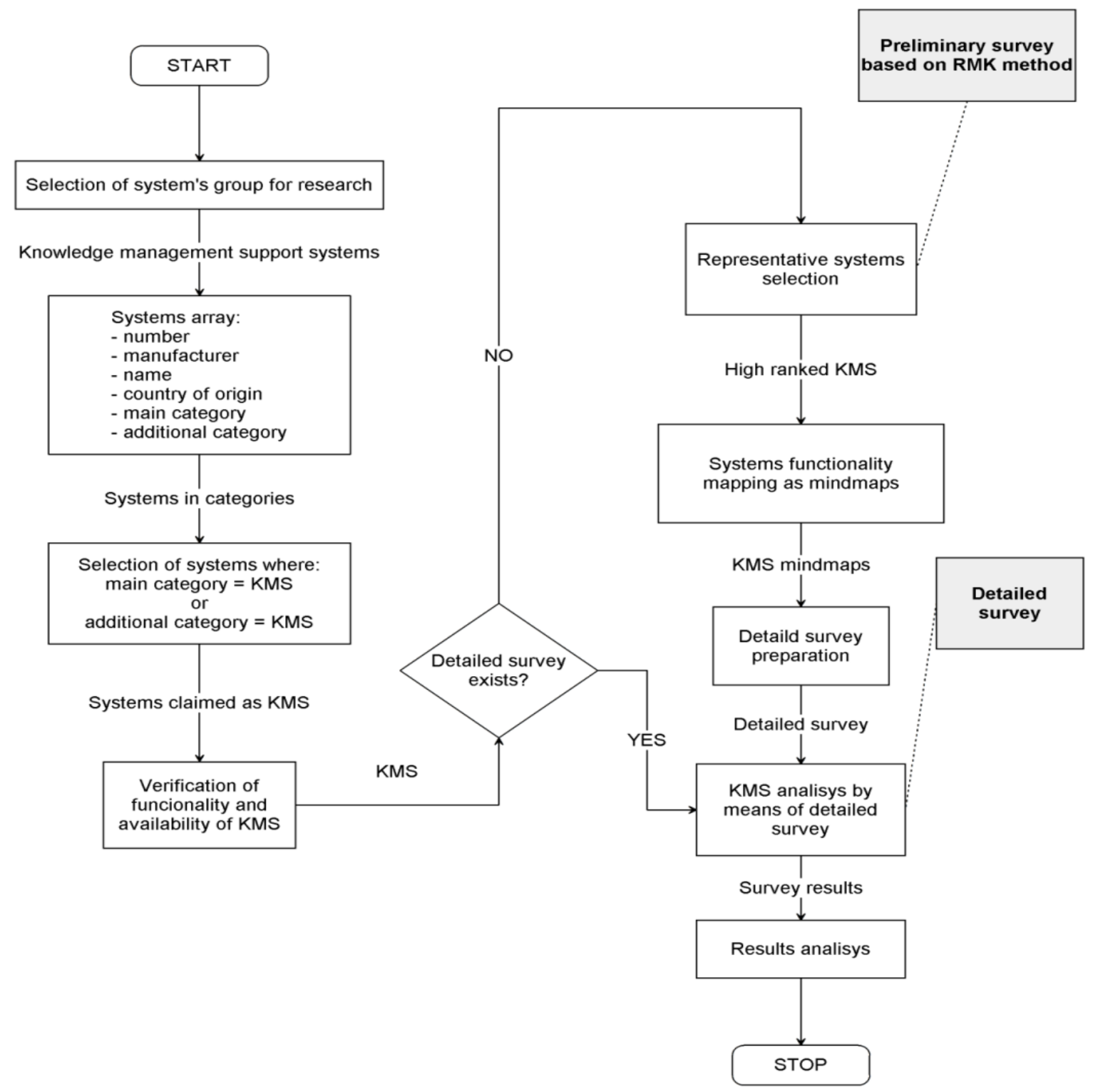

Figure 3. Case study block scheme (source: self study)

The aim of preliminary research was to create a ranging of systems, which would allow the selection of solutions best fitting the next step - detailed research. Solutions place in the first half of the rank were selected for the elaboration of a detailed questionnaire. Functionality of the systems was mapped in the form of knowledge maps (example of the map in the Figure 4).

\subsection{Detailed research}

Detailed questionnaire was used to re-check all 16 knowledge management systems with a higher level of detail. As a result of the research, connected with knowledge gathering and organization, it was determined that the system should be equipped with knowledge repository (94\% of positive answers) as well as should refer to knowledge sources trough abstract layer $(88 \%)$. Text data is the one most commonly stored in the system $(75 \%)$, rather than multimedia (50\%) and also the content indexing is the most popular way to allow quicker access to gathered data (63\%).

The use of metadata is a solution of repository functioning efficiency improvement (50\%) ant the XML language is the dominating one among technical solution. 


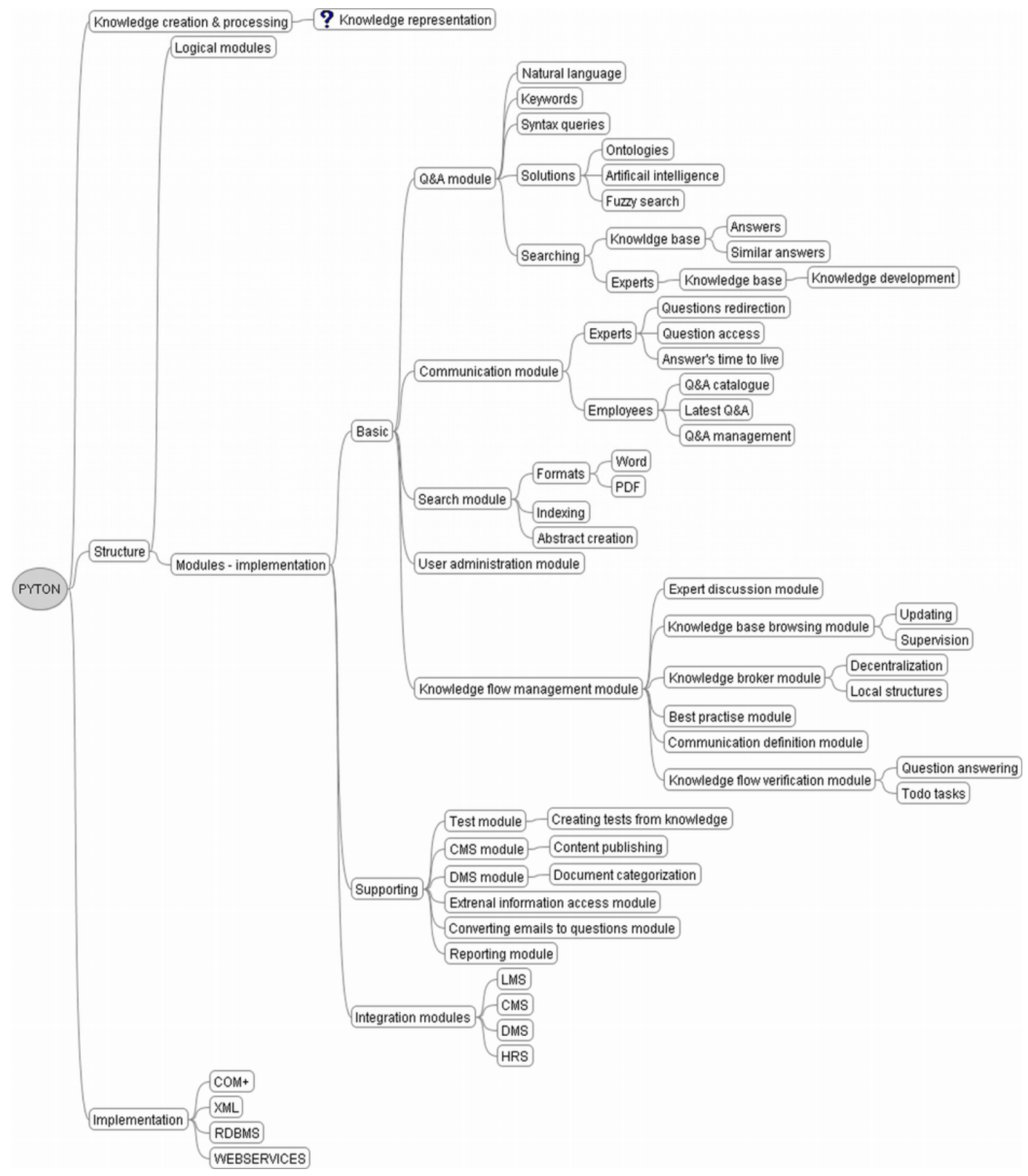

Figure 4. Knowledge map for the Pyton system (source: self study)

Knowledge use function analysis leads to a conclusion that practically no KMS can function without knowledge gathering mechanisms (94\%). Another way of accessing knowledge is the navigation through the resources $(69 \%)$ through browsing according to a determined hierarchy, reviewing dictionaries (38\%) or browsing through visualized knowledge resources $(25 \%)$, which is extremely helpful to spot the relation- ships between resources. Knowledge usage stimulating mechanisms, realized through the use of recommendations, are also playing an important role in knowledge management systems (50\%). To allow such possibility there has to be a knowledge evaluation system as well as system interface personalization, which allow it to be adjusted to requirements of particular users. 
Tacit knowledge cannot be codified and transferred directly. It can only be transferred through models, examples or metaphors, usually through the contact with a person who is gaining the knowledge. Finding an expert form the key area is essential to gather the necessary knowledge, which he or she possesses. Most of the researched systems are equipped with expert knowledge management mechanisms (69\%) and the most common basic solution is the expert browser (69\%), which allows to find proper human resources in the organization through searching criteria. The possibility to evaluate experts, directly or indirectly through the evaluation of their input into the knowledge management, is essential according to knowledge seekers. On the other hand experts value the possibility to create the "expert communities", organizational forms allowing creating and sharing knowledge, in the knowledge management system.

The possibility to create local structures is present in $50 \%$ of the systems. One of the essential issues is to allow the organization participants a real-time contact. Another possibility is to record knowledge transferred through telephone or audio and video conferences.

Knowledge requires protection from internal and external threats through administrative and security assurance solutions. One of the basic requirements is the authentication system $(63 \%)$. Another of such solutions is the groups (38\%) and roles (50\%), which allow defining general user authorization for particular system resources and functions.

Possibility to evaluate knowledge usage as well as the supervision of participants' activity can give important information to high management whether the knowledge management system with the use of IT tools is bringing the expected effects. The system should have the possibility both to present detailed reports for the system administrator and also analytical reports for the management.

\subsection{Knowledge management system research results}

Detailed research on knowledge management system function results allowed pointing out the development directions of particular functions:

- increase of the support for the use of ontology to build knowledge hierarchy as well as determine the meaning in knowledge resources,
- development of browsing with the use of natural language and the use of ontology,

- popularization of recommendation mechanisms and knowledge evaluation as well as the use of agents in order to make the knowledge resources easier to browse,

- popularization of the access to recorded information exchange between experts and knowledge seekers,

- implementation of expert communities creation mechanisms,

- increase of the influence of organization participants on the modeling of expert environment,

- increase of knowledge sharing processes that takes place during teamwork,

- implementation of real-time communication mechanisms (possibility to record the conversation in the repository for future use),

- introduction of roles and groups mechanisms in order to use default accessibility to resources for different users,

- increase in the usability and ergonomics of the access interfaces in order to avoid using general rights by the system administrators,

- implementation of protocols ciphered in the communication process,

- adjustment of the reports and statistics collection to the scope of knowledge management system in order to monitor its processes (lack of evaluation limits the possibility to verify the system usage).

One of the basic conclusions, after the detailed analysis of knowledge management systems, is the lack of complex solutions that aid knowledge management processes.

\section{$5 \quad$ Knowledge management system model}

KMS model, which is basing on knowledge management models and including current technological possibilities as well as situation in IT knowledge management systems, was created as a result of performed research. Basic model assumptions concerning its functions and modules are as following (see Figure 5):

- knowledge structured storing repository must exist in the system, apart from the format it was gathered in, 


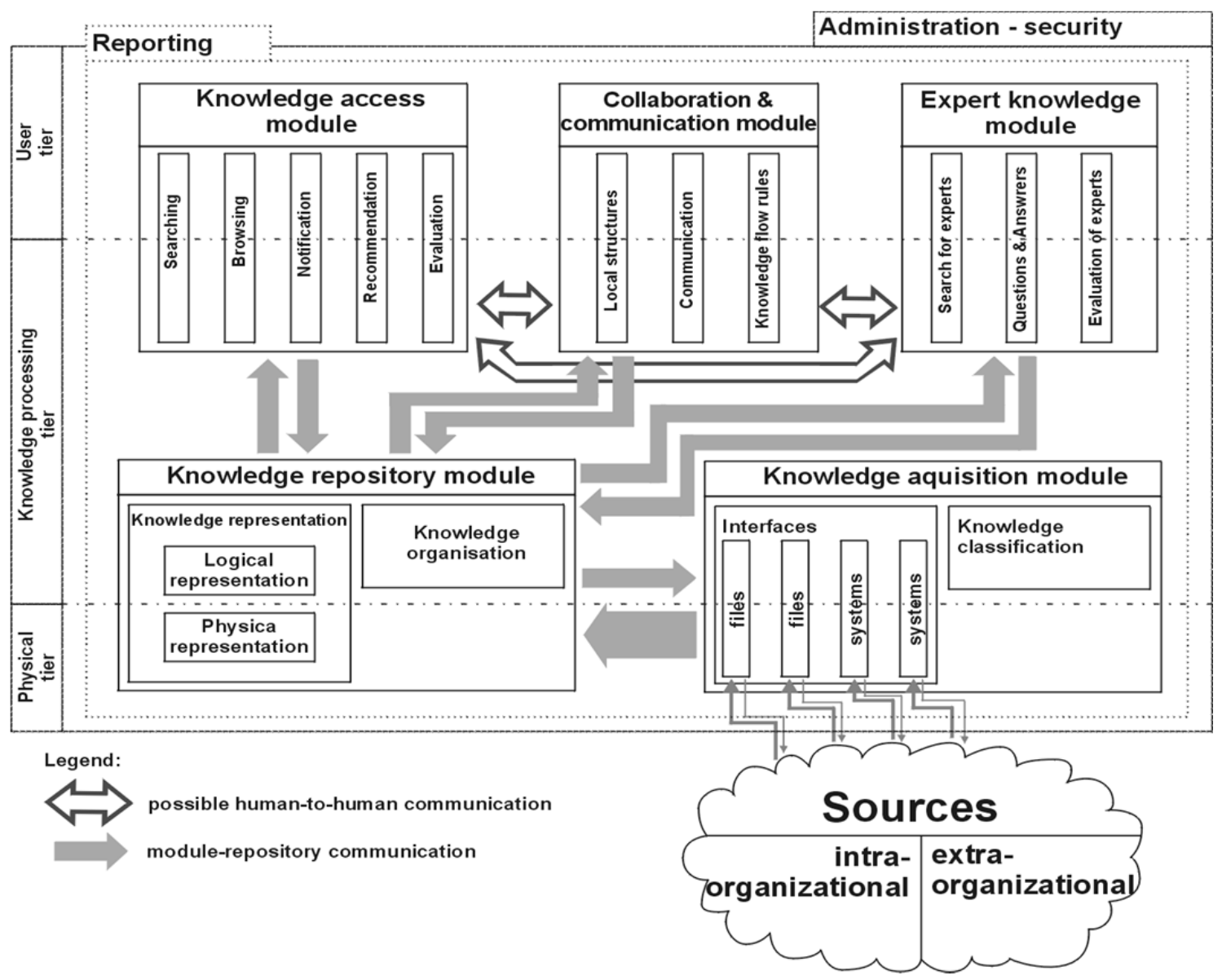

Figure 5. Functions and modules of knowledge management system (source: self study)

- knowledge gathering can be performed in two ways: automatic, on the basis of set criteria, and extorted, triggered by a conscious need of the system user or the knowledge repository,

- gathering knowledge from organizational internal and external sources is performed through interfaces adjusted to work with one source (or few sources that provide data in the same format),

- accessing knowledge from the repository can take place through navigation and browsing systems,

- access to the knowledge of other organization participants is realized through communication and cooperation as well as through expert knowledge management,

- cooperation and communication mechanisms should aid the gathering of the tacit knowledge and information and data exchange should be recorded in the repository,

- expert knowledge management system is necessary due to the critical significance of expert knowledge,
- administration and safety assurance concerns all areas of the system,

- all operations, realized through the system, are recorded for the need of detailed and analytical reporting.

Description of functionality of particular modules is presented in the following chapters.

\subsection{Knowledge management}

The necessity to search and browse through knowledge sources in different formats (text and multimedia) is a challenge for the KMS designers. One of the solutions to this problem is separating logical and physical representation of knowledge. The solution for knowledge representation depends on the number and type of knowledge sources, size of the organization as well as its financial and organizational possibilities. Knowledge representation module, which allows ordering the existing knowledge resources into a structure that allows easier, searching, browsing and resource relations creating. The basic functions of this module are: 
- storing knowledge in the KMS repository in the form of objects based on the frame theory. OWL is the knowledge representation language (knowledge objects that cannot be processed directly by the system are stored in the form of metadata, recorded in the OWL language),

- knowledge objects versionization, knowledge objects access control in order to assure the integrality of the repository and assurance of the multi-laguage nature of the objects,

- storing text in the repository,

- sorting of multimedia and data difficult to browse in the form of metadata (allows the possibility to add reviews),

- physical representation of the knowledge on the basis of database management system, file system and XML and its derivative files.

Knowledge stored in the repository cannot function without the determining of its organization. Basic function of the system is the possibility to create its own knowledge organization.

Other functions of the system are:

- assurance of the structure and hierarchy (organization) for the knowledge stored in the repository,

- organization of knowledge through ontology (use of OWL system for recording and storing of the ontology as well as the possibility to create much ontology).

\subsection{Knowledge gathering}

Another component necessary for the proper system functioning is the part responsible for gathering the knowledge stored in the repository. Knowledge possessing module functions are:

- automatic repository knowledge possessing either single or periodical (communication with external systems is realized through interfaces),

- manual repository knowledge gathering (communication of the KMS user realized through forms),

- assurance of form creation possibility,

- assuring the possibility of interface creation, which allows the change of knowledge provided from sources with different into the standard used in repositories (files and systems interfaces),

- manual, semi-automatic and automatic mechanisms of knowledge classification,

- knowledge resources classification in the form of text based on keywords analysis (system classifies knowledge resources on the basis of metadata analysis or the use of examples stored in the system),

- knowledge objects relation analysis,

- use of artificial intelligence,

- automatic change of the knowledge organization.

\section{$5.3 \quad$ Knowledge access}

The role of repository and knowledge gathering mechanisms is crucial from the point of view of correct functioning of the system. However, these components, responsible for knowledge access, are used directly by the organization participants. Knowledge access module needs to share solutions that allow knowledge fining in minimal time and with the use of minimal number of operations. Knowledge access module functions are:

- searching for knowledge in the repository (full-text search, use of syntax, parametric search),

- placement of the most popular content (or "best practices") search results in the top,

- knowledge browsing according to existing knowledge organization,

- creation of dictionaries and classifications (alphabetical and hierarchical),

- notification about the appearance of new knowledge objects and the modification of objects existing in the repository,

- defining of knowledge resources for the notification,

- defining programming agents,

- knowledge recommendation through the presentation of significant content/objects, corresponding content and highly evaluated content,

- possibility of knowledge quality evaluation, best practices nomination and the possibility to add comments to knowledge objects.

Knowledge access chapter is the description of the interface, which is used to access the knowledge management system. The basic user interface functions are:

- KMS user interface has the form of a slim customer,

- interface personalization possibility,

- posiibility to manage the user profile,

- communication with KMS via email,

- assurance of access to many platforms. 


\subsection{Expert knowledge management}

There can be many sources of knowledge in the organization, which can be stored in a repository. The possibility to manage this knowledge results from the functions described below:

- browsing through experts,

- searching according to the profile of an expert, activity history and the search with the use of natural language,

- searching for questions and answers,

- viewing questions and answers,

- possibility to ask question to experts through user interface (possibility of anonymous question asking),

- determining the priorities for asked questions,

- notifying experts about the questions that are waiting to be answered,

- possibility to evaluate the work organization and the quality of the experts' knowledge,

- proposing experts.

Described functions determine the functioning of an interface. Additional interface functions are:

- possibility to manage questions and answers,

- possibility to manage one's profile.

\subsection{Cooperation and communication}

Assurance of teamwork and communication mechanisms is one of the solutions supporting tacit knowledge management (results of these contacts should be placed in a repository). The main functions of the cooperation and communication model are:

- possibility to determine the scope of and the participants of the local structure as well as the assurance of the safety of a local structure,

- possibility to discuss,

- possibility to share resources,

- possibility to notify the group members,

- creating virtual rooms,

- communicator sharing,

- possibility of voice communication,

- conferences (real-time resource sharing).

\subsection{Administration and safety}

Administration and safety functions are not describing the additional module and are a collection of solutions implemented in KMS in order to assure proper system functioning. KMS is designated for the organization's participants that are active in different geographical areas and are using computer networks in order to gain access to the system resources. Basic functions provided by the system are:

- user management,

- group management,

- role management,

- access to resource groups, resources and resource elements,

- resource access according to roles and groups.

It is crucial to assure compliance of the KMS with the safety policy requirements in the organization as well as to train the users in organizational knowledge safety [8].

\subsection{Reporting}

Periodical knowledge evaluation and target verification in the knowledge management process is an essential issue according to Probst model. KMS should be equipped with in reporting mechanisms that realize the following functions:

- user activity monitoring in the scope of frequency and time of using the system,

- identification of important subjects, experts and resource decision making aiding,

- identification of lacks in organizational knowledge.

\subsection{Integration with other systems}

Many systems can function in an organization and every one of them can be a potential knowledge source for the KMS. However there are systems, whose integration is extremely important either because of the data they transfer or the role it is playing in the everyday work of organization's participants. There are also particular communication standards, which are realized through the following functions:

- possibility to integrate with other IT systems,

- possibility to integrate with systems coming from other producers,

- possibility to integrate with system classes (CMS, CRM, DMS, ERP, HRMS, LMS),

- the use of COM+ and CORBA standards,

- the use of Web Services standard. 
KMS model does not impose particular solutions, however the designers should use platforms that assure most of described functionalities and use open standards. Selection of an operational system or the database management system depends on the language or platform the implementation will be realized on.

Knowledge management system should be built with the use of such technology, which assures independence and transferability between different operational and database management systems. In case of implementation language selection it is necessary to take into consideration the possibility of application functioning in different systems.

\section{Knowledge management system prototype}

Knowledge management system prototype was built and implemented in order to verify the KMS model. It was based on function and module schematics of the knowledge management system (see Figure 4). The following modules were implemented in the prototype: knowledge repository, knowledge gathering, knowledge access and administration, safety and reporting functions. Cooperation and communication modules as well as expert knowledge management models were not used in the prototype due to limited resources.

\subsection{Preliminary assumptions for the KMSP}

It was determined that KMSP implementation should be possible in small and medium enterprises. The following additional requirements were set for the prototype:

- cost - system should use technologies with relatively low cost,

- standards - system should use standard technologies,

- internet - system should be based on protocols used in the internet,

- usability - use of the system should require only an internet browser.

KMSP was tested in two environments and freeware licenses technologies were used in the implementation. The following software was used: internet browser (Internet Explorer 6.0 and Mozilla Firefox 1.5.0.9), Apache HTTP Server 2.2.2 and 2.2.3 with PHP module version 4.4.4 and 4.4.2, MySQL database server version 5.0.22 and 5.0.24a, Windows XP Professional and Linux Slackware 10.2. operational systems. System functioning was correct in both cases and did not require any additional adjustments to fit the selected environment.

KMSP is built on the basis of internet protocols. Some of them, like HTTP, HTML or CSS, are imposed by the environments described above. Selection of OWL language for recording and storing of knowledge is compliant with $\mathrm{W} 3 \mathrm{C}$ requirements [11], which determine this language as the latest knowledge recording standard.

Interface design is based on the assumption that the user can only access the system with a computer equipped with any kind of operational system and internet browser. Unfortunately a knowledge engineer or knowledge expert needs to use additional (freeware) software to record knowledge in the OWL language (Protégé).

\subsection{KMSP architecture}

KMSP was built in a three-layer architecture [17], where user, knowledge usage, processing and physical level are based on applications presented in Figure 6.

KMSP plays an essential role in knowledge processing level. It was built on the basis of IPS system [5], which is a content management system with designed and manufactured modules as well as implemented libraries, which allowed managing the knowledge gathered in the OWL format.

Using file system in the physical level was limited to the storage of the OWL file, which includes ontology elaborated for the need of KMSP. It is also provided in this form from the knowledge engineer using Protégé software. External libraries were used to input OWL format data into the relation table of the database.

\subsection{Model functions implementation in the KMSP}

Knowledge management system implementation was limited to the functions with the highest priority. Function group connected with the logical representation of knowledge includes:

- knowledge objects representation function using OWL language allowed knowledge objects representation in a form similar to the one resulting from the frame theory,

- metadata usage function - default in the OWL language, 


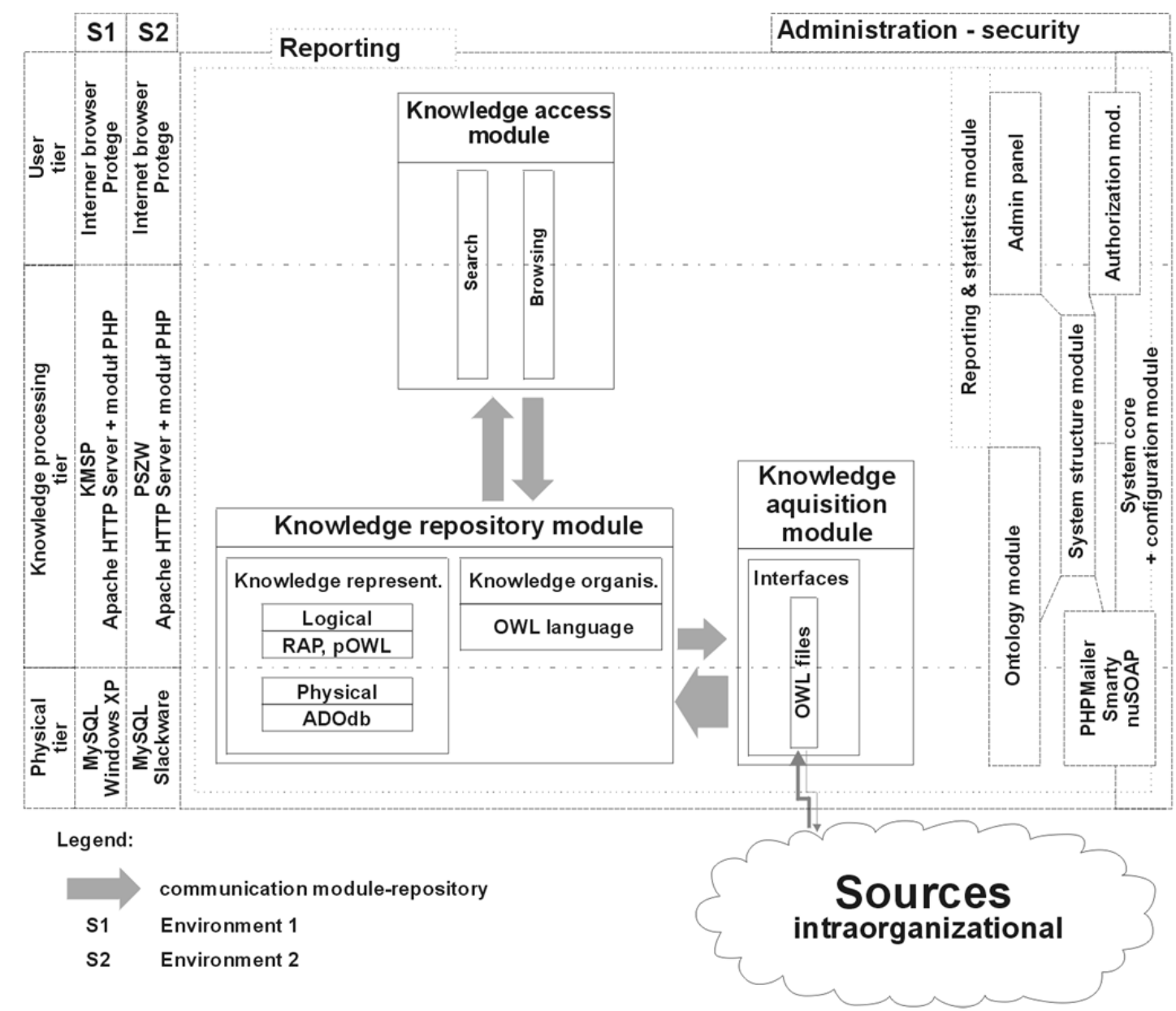

Figure 6. KMSP architecture in relation to KMS model functions and modules (source: self study)

- versionizing, access control and multilanguage functions - system does not support versionizing and multilanguage, access control is performed on a general level of all stored knowledge,

- text content support function (1/1) - current system supports only text content.

Function group connected with the physical representation of knowledge includes functions of physical knowledge representation in database management and XML file systems (XML is OWL derivative).

Knowledge organization includes assurance of proper structure and categorization of knowledge with the use of OWL language.

Repository knowledge gathering in KMSP is only performed manually by the knowledge engineer's work. Group of basic functions connected with knowledge gathering is:

- manual knowledge gathering (Protégé application),

- form creation functions,

- interface creation functions (OWL format files).
Automatic knowledge classification function was omitted in the prototype due to priorities set during the research as well as the complexity of implementation activities.

Knowledge access functions are crucial from the point of view of the system user and they can decide about the success of the implementation. In the first version of the prototype knowledge browsing was not implemented, only knowledge viewing was possible. In following questionnaire research it was revealed that $60 \%$ of the respondents thought of the knowledge browsing function as essential. The following issues were implemented in the prototype:

- browsing according to existing knowledge organization,

- dictionary and classification functions,

- general knowledge searching functions

- syntax use functions. 
Functions connected with knowledge resources notification, knowledge recommendation and knowledge evaluation were not implemented, even though they have a significant role in knowledge access. Low priorities decided about the implementation of knowledge recommendation and evaluation. In case of knowledge notification it was rejected due to accessibility dedicated only for the prototype research. Remaining knowledge management system functions were implemented to enable the functioning of the system.

\subsection{Course of experiment and system access}

The aim of the experiment was KMSP functioning verification that led to evaluation of KMS model assumptions. Object area of knowledge repository concerned the basic concepts from the area of enterprise management. KMSP was shared in internet at: www.pszw.wip.edu.pl/ (user: wiedza password: knowledge).

Knowledge resources can be viewed in a hierarchical manner. Index in alphabetical order (dictionary) can be accessed from all levels of knowledge browsing. Browsing function was added in the second version of the prototype due to questionnaire research results that indicated lack of functionality in this area. Request for experiment participation, using manual and questionnaires was distributed among potential respondents. Users were to use the system and check the issues described in the questionnaire. Afterwards the questionnaire was filled in and sent back to the author. In addition, the "Experiments" bookmark included instructions necessary to perform experiments in the scope of knowledge management with the use of KMSP (see Figure 7).

\section{PSZW - Prototyp Systemu Zarządzania Wiedzą}

\begin{tabular}{|c|c|c|c|}
\hline$\gg$ & Strona główna & \multicolumn{2}{|l|}{ Jesteś tu: Podstawy biznesu } \\
\hline » & Podstawy biznesu & \multirow{3}{*}{ Wiedza z podstaw prowadzenia biznesu } & \\
\hline$\gg$ & Indeks alfabetyczny & & \\
\hline$\gg$ & Wyszukiwarka & & \\
\hline 》 & Pliki do pobrania & \multicolumn{2}{|r|}{ Klasy } \\
\hline$\gg$ & Eksperymenty & \multicolumn{2}{|l|}{ A } \\
\hline$\gg$ & Mapa serwisu & Adwokat & Klasy główne -> Inne -> Zawody_Spolk__Partnerskiej -> Adwokat \\
\hline$\gg$ & Kontakt & Akcje & Klasy główne -> Inne -> Dane -> Akcje \\
\hline \multirow[t]{25}{*}{$\gg$} & 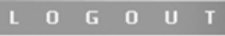 & Akcjonariusz & Klasy główne -> Osoba -> Wspolnik -> Akcjonariusz \\
\hline & & Akt_Prawny & Klasy główne -> Akt_Prawny \\
\hline & & Akt_wlasnosci & Klasy główne -> Dokument -> Tytul_do_Lokalu -> Akt_Wlasnosci \\
\hline & & Aptekarz & Klasy główne -> Inne -> Zawody_Spolk_Partnerskiej -> Aptekarz \\
\hline & & Architekt & Klasy główne -> Inne -> Zawody_Spolk__Partnerskiej -> Architekt. \\
\hline & & B & \\
\hline & & Bank & Klasy główne -> Instytucja -> Bank \\
\hline & & Biegly_Rewident & Klasy główne -> Inne -> Zawody_Spolk__Partnerskiej -> Biegly_Rewident \\
\hline & & Broker_Ubezpieczeniowy & Klasy główne -> Inne -> Zawody_Spolk__Partnerskiej -> Broker_Ubezpieczeniowy \\
\hline & & C & \\
\hline & & CIT & Klasy główne -> Obciazenie -> Podatek ->CIT \\
\hline & & Czas_trwania & Klasy główne -> Inne -> Dane -> Czas_trwania \\
\hline & & Czlonek_Rady_Nadzorczej & Klasy główne -> Osoba -> Czlonek_Rady_Nadzorczej \\
\hline & & Czlonek_Zarzadu & Klasy główne -> Osoba -> Czlonek_Zarzadu \\
\hline & & D & \\
\hline & & Dane & Klasy główne -> Inne -> Dane \\
\hline & & Dane_wspolnikow & Klasy główne -> Inne -> Dane -> Dane_wspolnikow \\
\hline & & Dokument & Klasy główne -> Dokument \\
\hline & & Dokument_Firmowy & Klasy główne -> Dokument -> Dokument_Firmowy \\
\hline & & Doradca_Podatkowy & Klasy góówne -> Inne -> Zawody_Spolk__Partnerskiej -> Doradca_Podatkowy \\
\hline & & Dowod_Osobisty & Klasy główne -> Dokument -> Dowod_Osobisty \\
\hline & & Duze_Przedsiebiorstwo & Klasy główne -> Przedsiebiorstwo -> Duze_Przedsiebiorstwo \\
\hline & & Dzial_Podatkow_Posrednich & Klasy główne -> Instytucja -> Urzad_Skarbowy -> Dzial_Podatkow_Posrednich \\
\hline & & Dzial_Podatku_Dochodowego & Klasy główne -> Instytucja -> Urzad_Skarbowy -> Dzial_Podatku_Dochodowego \\
\hline & & Dzial_Podatku_od_Czynnosci_Cywilnoprawnych & $\begin{array}{l}\text { Klasy główne -> Instytucja -> Urzad_Skarbowy -> } \\
\text { Dzial_Podatku_od_Czynnosci_Cywilnoprawnych }\end{array}$ \\
\hline
\end{tabular}

Figure 7. KMSP user interface (source: self study) 


\subsection{Prototype research}

Most of the research included issues that needed to be verified with the use of methods originating from social research. Five-point Likert [9] scale, compliant with the Rensis Likert method, was used to design the questionnaire and allowed to determine the degree of acceptance, view or feeling on researched issues.

The respondent group included two environments: scientific (students) and business. First part of the questionnaire included questions that gave a general view on knowledge management and the use of computer skills. Over $60 \%$ of respondents were familiar with the concept of knowledge management and most (59,2\%) of them identified IT resources management with this concept and knowledge resources processing (34,7\%). Respondents determined their computer skills as good or very good $(70,2 \%)$.

Ability to search for information was determined as good by $73,8 \%$ of the respondents and the number of respondents familiar with tolls like internet forums, communicators and chat rooms was considerably different in each of the two groups. It is connected with the correlation of universality of such tools in different age groups, because the correlation index between the age and the knowledge of the tools equaled $-0,56$, what indicates that the distribution of this features is negative linearly. In addiction selected group of respondents participated in the research and questionnaire research results are credible.

Second group of questions concerned the KMS prototype. Over $82 \%$ of respondents accepted the descriptive forms of knowledge transferring (manuals, text books). Question about structured knowledge description form, recorded in class hierarchy and its mutual relations, was in favor of $64,8 \%$ of respondents and $24,4 \%$ of respondents thought of such form of knowledge transferring as not suitable.

Knowledge resources browsing was seen as not innovative by $61,9 \%$ of respondents. It can be treated as either the failure in reaching required knowledge resources browsing solution or an advantage - adjusting user interface to common standards.

In question on knowledge hierarchy (its content, not form) $80,7 \%$ of respondents treated it as understandable. Three following questions concerned the presentation of particular knowledge classes. In case of the descriptions of knowledge classes most of the respondents $(61,4 \%)$ indicated that the descriptions were not sufficient. Features of particular classes were understandable for $64,3 \%$ respondents. It was indicated that also the descriptions of knowledge classes are insufficient by $56,1 \%$ of respondents and $43,9 \%$ found it sufficient. To sum up, answers confirmed the popularity of descriptive knowledge transferring and the form of particular classes' properties presentation.

The remaining questions dealt with functions not present in the system, but desired by the users. First one concerned knowledge browsing - $29,8 \%$ of respondents noted that this function was missing. However $58,3 \%$ of the respondents decided that knowledge browsing is necessary, therefore every knowledge management system should be equipped with it.

Following questions concerned knowledge evaluation:

- answer distribution does not give a direct answer to this question,

- $36,9 \%$ of the respondents are missing such possibility,

- $32,1 \%$ find it indifferent and $31 \%$ thinks of it as redundant,

- on the contrary $54,8 \%$ of respondents think that adding comments and corrections to the knowledge is necessary.

Additional questions dealt with advanced aspects of knowledge management systems and verified the correctness of some of the assumptions of the KMS modules. $47,6 \%$ of the respondents think that the possibility to create knowledge hierarchy by the users should be limited and $36,9 \%$ would like to have such possibility.

Next question researched the need of communication between KMS users (chat-rooms, internet forums etc.). $77,4 \%$ of the respondent think that such solutions should be implemented in the system.

Most of the respondents think that register of such FAQ's and conversations should be implemented in the system and accessible in the knowledge repository. $84,5 \%$ consider the presence of experts in the system as crucial (in both of the environments). Email was the most common answer for the communication channel with an expert. Final question dealt with data security.

$20,2 \%$ of the respondents think that knowledge should be more secure than other enterprise resources and $27,4 \%$ required restricted use of knowledge.

Answers of the respondents lead to the following conclusions:

- research respondent group was confirmed, 
- use of KMSP form organizational knowledge management was verified,

- there was no direct answer about the necessity of knowledge structuring in KMS model,

- browsing function implementation was found as crucial and added in the second version of the prototype,

- cooperation and communication modules significance was confirmed as well as the expert knowledge management; user preference of IT tools for KMS communication was determined.

Correctness of the KMS model was verified and some issues, designated for further study including KMS implementation variants dependent of the organization type and the influence of KMS on the knowledge management in an organization, were identified on the basis of KMSP implementation and research results.

\section{$7 \quad$ Summary}

Construction and verification process of the relation model for a knowledge management system in an organization brought many tools to its receivers. Extended Classification Method (ECM) of knowledge management systems can be used by scientists and designers to select a KMS for their study and the knowledge management system analysis method can be used to research the existing KMS.

KMS system should aid the system designers to create solutions compliant with current knowledge level and the KMS prototype can lead to an implementation of a complete KM system or development of existing system in an organization. Scientists can use the KMS prototype as a basis for knowledge management systems research and the high management and IT managers can analyze KMSP as an example of practical implementation of KMS in a business environment.

Further research directions were determined as a result of the study: elaboration of KMS variants according to the complexity of KMS relation model and further research with KMS prototype implementation, including the implementation of all modules and relation functions.

\section{$8 \quad$ References}

[1] Ackoff R.L. - From Data to Wisdom [in] Journal of Aovlied Systems Analysis. No. 16, 1989.

[2] Carayannis E. - Fostering Synergies between Information Technology and Managerial and Organizational Cognition: the Role of Knowledge Management [in] Technovation, No. 19, 1999.

[3] Cobos R., Esquivel J.A., Alaman X. - IT Tools for Knowledge Management: A Study of the Current Situation, UPGRADE [in] The European Online Magazine for the IT Professional, Vol. III, No. 1, February 2002, www.upgrade-cepis.org., pp. 6065.

[4] Davenport T.H., Prusak L. - Working Knowledge: How Organizations Manage What They Know. Harvard Business School Press, Boston 1998.

[5] Grafinet Sp. z o.o.: IPS - Internet Publishing System [online]. URL: http://www.gt.pl/ips.php, December 2006.

[6] Grudzewski W.M., Hejduk I. - Zarzqdzanie wiedza w przedsiębiorstwie. Difin, Warszawa 2004.

[7] Hayek F.A. - Individualism and Economic Order. University of Chicago Press, Chicago 1996.

[8] Kotarba W. - Ochrona wiedzy w Polsce. Instytut Organizacji i Zarządzania w Przemyśle ORGMASZ, Warszawa 2005.

[9] Likert R. - A Technique for the Measurement of Attitudes [in] Archives of Psychology, No. 140, 1932, pp. 1-55.

[10] Łobejko S. - Systemy informacyjne w zarzadzaniu wiedza $i$ innowacja $w$ przedsiębiorstwie. Oficyna Wydawnicza SGH, Warszawa 2005.

[11] McGuinness D.L., van Harmelen F. - OWL Web Ontology Language Overview. Cambridge, URL: www.w3.org/TR/owl-features/, February 2004,.

[12] Marshall A. - Principles of Economics. Macmillan and Co. Ltd., London 1890.

[13] Nonaka I., Takeuchi H. - Kreowanie wiedzy w organizacji. Poltext, Warszawa 2000.

[14] Polanyi M. - The Tacit Dimension. Anchor Books, New York 1967.

[15] Schumpeter J.A. - Theory of Economic Development. Transaction Publishers, New Brunswick 1983.

[16] Probst G., Raub S., Romhardt K. - Zarzqdzanie wiedza $w$ organizacji. Oficyna Ekonomiczna, Kraków 2002. 
[17] Sadoski D. - Three Tier Software Architectures, URL: www.sei.cmu.edu/str/descriptions/ threetier_body.html, February 2000.

[18] Simon H.A. - The Science of the Artificial. MIT Press, Boston 1969.

[19] Skyrme D.J. - Knowledge Networking, Creating the Collaborative Enterprise. Butterworth-HeinerMann, Oxford 1999.
[20] Strojny M. - Portale korporacyjne a zarzadzanie wiedza - raport z badań, e-mentor. No. 2 (14), April 2006, pp. 50-54.

[21] The KM Connection - Knowledge Management Product Guide. URL: www.kmconnection.com/ pguide/, May 2006. 